\title{
Applicability of ELISA with different antigens to diagnose varying levels bovine cysticercosis
}

\section{Desempenho do teste ELISA no diagnóstico da cisticercose em bovinos com diferentes antígenos e níveis de infecção}

\author{
Letícia Ferreira da Silva ${ }^{1 *}$; Paulo Sérgio de Arruda Pinto ${ }^{2}$; \\ Camilla Taveira Ducas Duarte ${ }^{1}$; Tatiane de Oliveira Santos ${ }^{3}$; \\ Emilio Campos Acevedo Nieto'; \\ Rafaella Paola Meneguete dos Guimarães Peixoto ${ }^{1}$
}

\begin{abstract}
The efficiency of larval Taenia crassiceps (Tcra) antigens was evaluated by enzyme-linked immunosorbent assay (ELISA) to diagnose bovine cysticercosis. Three types of antigens were evaluated: total (T), total sonicated (Ts), and membrane (M); these samples included positive and negative control sera for cysticercosis, as well as sera for other pathologies. The sensitivity rates of ELISA were determined to be 85.0 and $81.25 \%$ for $\mathrm{T}$ antigen, 82.5 and $78.75 \%$ for Ts antigen, and 80.0 and $80.0 \%$ for $\mathrm{M}$ antigen, using cut-off points with standard deviations (SD) of 2 and 3, respectively; the specificity rates of ELISA were 47.5 and $58.75 \%$ for $\mathrm{T}$ antigen, 65.0 and $73.75 \%$ for Ts antigen, and 58.75 and $62.5 \%$ for $\mathrm{M}$ antigen, using 2 and 3 SD cut-off points, respectively. These results demonstrated that ELISA, which displayed a better performance in the detection of experimentally infected animals, had a higher sensitivity than the anatomical and pathological examination performed (during routine post-mortem inspections) in other studies. However, the post-mortem investigation is highly specific, and the specificity was higher than that of ELISA. Therefore, a combination of these diagnostic tests must be utilized for the accurate detection of bovine cysticercosis, demonstrating the practical applicability of ELISA.
\end{abstract}

Key words: Bovine cysticercosis, ELISA, performance rates, Taenia crassiceps

\section{Resumo}

Ensaios foram conduzidos para avaliar a eficiência de antígenos de larva de Taenia crassiceps (Tcra) no teste ELISA para o diagnóstico da cisticercose bovina. Três antígenos foram avaliados: total (T), total sonicado (Ts) e de membrana (M). As amostras analisadas foram soros-controle positivos e negativos para a cisticercose, além de soros de bovinos com outras patologias. As taxas de sensibilidade para o teste ELISA foram respectivamente, com 2 e 3 desvios-padrão, 85,0 e 81,25\% para o antígeno T, 82,5 e $78,75 \%$ para o antígeno Ts e 80,0 e $80,0 \%$ para o antígeno $\mathrm{M}$; as taxas de especificidade, com 2 e 3 desvios-padrão, foram respectivamente: 47,5 e 58,75\% para o antígeno T, 65,0 e 73,75\% para o antígeno Ts e 58,75 e $62,5 \%$ para o antígeno M. Estes resultados demonstram que o ELISA, apesar de apresentar melhor desempenho em detectar animais experimentalmente infectados, apresentou taxa de sensibilidade superior ao exame anatomopatológico realizado durante a rotina de inspeção relatada

\footnotetext{
${ }^{1}$ Médicos Veterinários, Discentes do Curso de Doutorado em Medicina Veterinária, Universidade Federal de Viçosa, UFV, Viçosa, MG, Brasil. E-mail: leticiaafs@gmail.com; camillatsd@yahoo.com.br; ecanieto@gmail.com; rafinhapaola@hotmail.com

2 Médico Veterinário, Prof. Dr., Dept ${ }^{\circ}$ de Veterinária, UFV, Viçosa, MG, Brasil. E-mail: pintopsa@ufv.br

${ }^{3}$ Médica Veterinária, Dra ${ }^{\mathrm{a}}$, UFV, Viçosa, MG, Brasil. E-mail: tatyvetoli@hotmail.com

* Author for correspondence
} 
por outros estudos. No entanto, o exame post mortem é superior quanto a especificidade, uma vez que é considerado altamente específico. Assim, a combinação de ambas as técnicas diagnósticas deve ser valorizada na deteç̧ão da cisticercose bovina, demonstrando a aplicabilidade prática do ELISA.

Palavras-chave: Cisticercose bovina, ELISA, Taenia crassiceps, taxas de desempenho

\section{Introduction}

Bovine cysticercosis, caused by human intestinal parasite Taenia saginata larvae, presents food safety and economic implications in the bovine meat industry. The economic impact on the beef sector is related to the condemnation of heavily infected carcasses and the increase in the cost of mildly infected carcasses, resulting from the mandatory cold treatment (ALLEPUZ et al., 2012; MIRANDA, 2002; SCANDRETT et al., 2012). From the food safety and health point of view, the consumption of infected meat would promote the development of taeniasis in humans.

This zoonosis has a cosmopolitan distribution, and occurs more frequently in developing countries (OLIVEIRA et al., 2011). In Brazil, bovine cysticercosis is considered to be the major cause of rejection of bovine carcasses due to established rules by the Federal Inspection Service (FUKUDA et al., 2003).

Post-mortem inspection, which is the major control measure for bovine cysticercosis, does not adequately detect mildly infected carcasses, and has a sensitivity of 10-50\% (ABUSEIR et al., 2006; CALVO-ARTAVIA et al., 2012; EICHENBERGER et al., 2011; SCANDRETT et al., 2009). Therefore, the control of taeniasis in humans may be hampered by the low sensitivity of the meat inspection protocols, requiring the development and application of more efficient testing methods (DORNY; PRAET, 2007).

Consequently, efforts have been directed towards the development of more reliable diagnostic techniques, including ante-mortem methods, such as serological tests (SMITH et al., 1991). The use of enzyme-linked immunosorbent assay (ELISA) has been proposed for the diagnosis of bovine cysticercosis; however, the commonly used ELISA protocols have been unable to adequately detect antibodies in naturally infected animals, which, in most cases, have milder forms of the infection (GEERTS et al., 1981; MONTEIRO et al., 2006).

As the antigen determines the implementation of ELISA for the detection of antibodies, some studies have focused on the evaluation and comparison of different antigenic preparations (OGUNREMI; BENJAMIN, 2010). Promising results have been obtained using heterologous antigens of Taenia crassiceps; the use of these antigens has major advantages, such as easy maintenance in the laboratory and improved homogeneity between the antigenic lots (GEERTS et al., 1981, MONTEIRO et al., 2006; PINTO et al., 2006).

Therefore, the aim of this study was to evaluate the performance of ELISA using three antigens of Taenia crassiceps against various categories of control sera obtained from slaughtered cattle, considering the variations in infection levels and the conditions of the cattle.

\section{Material and Methods}

This test involved a comparative analysis of the following Taenia crassiceps (Tcra) antigens: total $(\mathrm{T})$, total sonicated (Ts), and membrane (M). The antigens were obtained by intraperitoneally innoculating 30 day old $\mathrm{BALB} / \mathrm{c}$ female mice, according to the method described by Vaz et al. (1997).

The $\mathrm{T}$ antigen was produced by the following method. The cysticerci were frozen, and subjected to dehydration "overnight" by lyophilization. The lyophilized cysticerci were ground in a porcelain mortar, and the obtained powder was weighed 
and solubilized in $0.15 \mathrm{M}$ saline solution; a final ratio of 6.5 to $10 \%$ was obtained. This mixture was homogenized in an ice bath using a Potter homogenizer. The homogenized solution was centrifuged at $17400 \times g$ for $30 \mathrm{~min}$ at $4^{\circ} \mathrm{C}$, and the supernatant separated. Protease inhibitor Sigma P7626 was added to the resulting material $(0.25$ $\mathrm{M}-10 \mu \mathrm{L} \mathrm{mL}^{-1}$ ) (phenylmethanesulfonyl fluoride (PMSF); Sigma Chemical Co., Ltd., St Louis, MO, USA), and the antigen was stored at $-20^{\circ} \mathrm{C}$ until further use.

The Ts antigen of Tcra larvae was prepared using a method similar to that of the $\mathrm{T}$ antigen; however, after homogenization, the material was subjected to ultrasound treatment according to the method proposed by Minozzo et al. (2004). The solution was subjected to four cycles of sonication at a frequency and amperage of $20 \mathrm{Khz}$ and $1 \mathrm{~mA}$, respectively, at $30 \mathrm{~s}$ intervals. Following this, the material was centrifuged at $17400 \times g$ for $30 \mathrm{~min}$ at $4{ }^{\circ} \mathrm{C}$; PMSF $\left(0.25 \mathrm{M}-10 \mu \mathrm{L} \mathrm{mL}^{-1}\right)$ was added to the supernatant. The antigen was stored at $-20^{\circ} \mathrm{C}$ until further use.

The antigen $\mathrm{M}$ was obtained by centrifugation of the cysticerci at $35000 \times g$ for $30 \mathrm{~min}$ at $4^{\circ} \mathrm{C}$. This resulted in the rupture of the vesicles, and eventual separation of the supernatant; the membranes (sediment) were frozen at $-20^{\circ} \mathrm{C}$ and subsequently subjected to the same steps as described for the preparation of the $\mathrm{T}$ antigen.

Four categories of control sera were used for ELISA: sera from cattle experimentally infected with 120,000 T. saginata eggs (40), sera from naturally infected cattle with a mild form of the infection (one cysticercus observed during postmortem inspection; 10 sera samples) and moderate to heavy infection (more than one cysticercus observed during post-mortem inspection; 30 sera samples), cattle sera negative for cysticercosis (40), and sera from cattle with other diseases (40), such as hydatidosis (15), fascioliasis (15), and tuberculosis (10).
The diagnoses of all animals were confirmed by pathological examinations conducted during the routine post-mortem inspection in refrigerated slaughterhouses, based on the technical specifications laid down in the routine procedures proposed by the Federal Inspection Service (BRASIL, 1971). Cattle with viable cysts were selected from among the animals that were positive for cysticercosis.

ELISA was performed with different antigenic preparations of Tcra larva, at a concentration of 40 $\mu \mathrm{g} \mathrm{mL}{ }^{-1}$.

Polystyrene plates were sensitized for $1 \mathrm{~h}$ at $37^{\circ} \mathrm{C}$ with antigens that was diluted in $0.5 \mathrm{M}$ carbonate-bicarbonate buffer ( $\mathrm{pH}$ 9.6) to obtain the previously mentioned final concentration. Blocking of reactive sites was performed (skimmed milk at $5 \%$ in PBS pH 7.4), for 1 hour at $37^{\circ} \mathrm{C}$. The serum samples were diluted to $1: 100$ with a solution of skimmed milk prepared in 1\% PBS ( $\mathrm{pH} 7.4)$, and were incubated for $30 \mathrm{~min}$ at $37^{\circ} \mathrm{C}$. Anti-IgG bovine conjugate A-5295 (Sigma Chemical Co., Ltd., St Louis, MO, USA) was added to these plates at a dilution of 1:1250, and the plates were incubated as previously described. The plates were washed thrice after each $5 \mathrm{~min}$ incubation step with saline solution containing $0.05 \%$ Tween-20 in an Automatic Microplate Washer ELX50 (Bio Tek Instruments Inc., Winooski, VT, USA), in order to remove the excess reagents. The reaction was visualized by incubating the plates with OPD solution $(0.1 \%)$ and $\mathrm{H}_{2} \mathrm{O}_{2}(0.003 \%)$ in citrate-phosphate buffer $(0.2 \mathrm{M}$, $\mathrm{pH}$ 5.0) for $5 \mathrm{~min}$. The reaction was stopped with $4 \mathrm{~N} \mathrm{H}_{2} \mathrm{SO}_{4}$. The optical densities were read at 492 $\mathrm{nm}$ using a spectrophotometer. One $100 \mu \mathrm{L}$ of all reagents were added to the plates, except for the blocking solution $(200 \mu \mathrm{L})$.

Two negative control sera (cattle observed to be negative for cysticercosis during post-mortem inspection) and a positive control serum (cattle experimentally infected with $T$. Saginata eggs) were added to each plate in order to calculate the cut-off point, and for plate correction. 
The values were adjusted to those of a standard plate in order to correct the variations in the ELISA, using the following formulae: Factor $(F)=\frac{\mathrm{Po}_{\mathrm{o}}-\mathrm{No}}{\mathrm{Pt}_{\mathrm{N}} \mathrm{Nt}}$; Adjusted Value $=\mathrm{F} \times(\mathrm{St}-\mathrm{Nt})+\mathrm{No}$

Where, Po is the average value of the positive controls in the standard plate, No denotes the average value of the negative controls in the standard plate, Pt denotes the average value of the positive controls in the test plate, $\mathrm{Nt}$ is the average of the negative controls in the test plate, and St denotes the average value for the tested sample.

The positivity and negativity of each sample was determined by calculating the cut-off points, which were defined as the average of the optical densities (O.D.) of the reactions of the negative control sera, plus two or three standard deviations (SD).

The performance was evaluated by calculating the sensitivity and specificity of the ELISA, and the results (positive and negative) were listed in contingency tables.

This study was approved by the Ethics Committee in Research on the Use of Animals (Process 20/2012) of the Universidade Federal de Viçosa.

\section{Results}

The results of the reactions (positive and negative) for each group of control sera obtained by ELISA, using the different antigens and cut-off points, are listed in Table 1. The cut-off points were 0.111 and 0.116 for antigen $T, 0.133$ and 0.143 for antigen Ts, and 0.074 and 0.078 for antigen $\mathrm{M}$, with SD of 2 and 3, respectively. Samples with OD equal to or greater than the cut-off point were considered to be positive, while those lower than the OD were considered to be negative.

Table 1. Frequency of positive (Pos) and negative (Neg) reactions for bovine cysticercosis as detected by ELISA, based on the applied cut-off points and antigens used.

\begin{tabular}{|c|c|c|c|c|c|c|c|c|c|c|c|c|}
\hline \multirow{4}{*}{$\begin{array}{l}\text { Groups of } \\
\text { control sera }^{\text {a }}\end{array}$} & \multicolumn{12}{|c|}{ Cut-off point (DP) } \\
\hline & \multicolumn{6}{|c|}{$2 \mathrm{SD}$} & \multicolumn{6}{|c|}{$3 \mathrm{SD}$} \\
\hline & \multicolumn{2}{|c|}{$\mathrm{T}$} & \multicolumn{2}{|c|}{ Ts } & \multicolumn{2}{|c|}{$\mathrm{M}$} & \multicolumn{2}{|c|}{$\mathrm{T}$} & \multicolumn{2}{|c|}{ Ts } & \multicolumn{2}{|c|}{$\mathrm{M}$} \\
\hline & Pos & Neg & Pos & Neg & Pos & Neg & Pos & $\mathrm{Neg}$ & Pos & $\mathrm{Neg}$ & Pos & $\mathrm{Neg}$ \\
\hline 1 & 40 & 0 & 40 & 0 & 40 & 0 & 40 & 0 & 40 & 0 & 40 & 0 \\
\hline 2 & 28 & 12 & 26 & 14 & 24 & 16 & 25 & 15 & 23 & 17 & 24 & 16 \\
\hline $2 \mathrm{a}$ & 22 & 8 & 22 & 8 & 20 & 10 & 20 & 10 & 19 & 11 & 20 & 10 \\
\hline $2 b$ & 6 & 4 & 4 & 6 & 4 & 6 & 5 & 5 & 4 & 6 & 4 & 6 \\
\hline 3 & 11 & 29 & 7 & 33 & 9 & 31 & 8 & 32 & 2 & 38 & 7 & 33 \\
\hline 4 & 31 & 9 & 21 & 19 & 24 & 16 & 25 & 15 & 19 & 21 & 23 & 17 \\
\hline
\end{tabular}

SD: Standard deviation; T: Total antigen; Ts: Total sonicated antigen; M: Membrane antigen

${ }^{a} 1$ : sera from experimentally infected cattle; 2: sera from cattle naturally infected during post-mortem inspection ; 2a: sera from cattle naturally infected with more than one cysticercus; $2 b$ : sera from cattle naturally infected with one cysticercus; 3 : sera from cattle determined to be negative for cysticercosis during post-mortem inspection; 4: sera from cattle with other diseases.

The sensitivity and specificity of the three antigens (tested with ELISA) are summarized in Table 2. The $\mathrm{T}$ antigen displayed the highest sensitivity, while the Ts antigen showed the highest specificity; the membrane antigen showed moderate activity. 
Table 2. The rate of performance (\%) of ELISA obtained based on 2 and 3 standard deviation (SD) cut-off points using different antigens of $T$. crassiceps and groups of control sera, based on the post-mortem inspection.

\begin{tabular}{cccccccc}
\hline \multirow{2}{*}{$\begin{array}{c}\text { Performance } \\
\text { Parameters }\end{array}$} & \multirow{2}{*}{$\begin{array}{c}\text { Groups of } \\
\text { control sera }^{a}\end{array}$} & \multicolumn{7}{c}{ T } & \multicolumn{7}{c}{ Antigen/cut-off point (SD) } \\
\cline { 3 - 8 } & 1 & 100.0 & 100.0 & 100.0 & 100.0 & 100.0 & 100.0 \\
& 2 & 70.0 & 62.5 & 65.0 & 57.5 & 60.0 & 60.0 \\
\multirow{3}{*}{ Sensitivity } & $2 \mathrm{a}$ & 73.3 & 66.7 & 73.3 & 63.3 & 66.7 & 66.7 \\
& $2 \mathrm{~b}$ & 60.0 & 50.0 & 40.0 & 40.0 & 40.0 & 40.0 \\
& $1+2$ & 85.0 & 81.25 & 82.5 & 78.75 & 80.0 & 80.0 \\
\hline \multirow{3}{*}{ Specificity } & 3 & 72.5 & 80.0 & 82.5 & 95.0 & 77.5 & 82.5 \\
& 4 & 22.5 & 37.5 & 47.5 & 52.5 & 40.0 & 42.5 \\
& $3+4$ & 47.5 & 58.75 & 65.0 & 73.75 & 58.75 & 62.5 \\
\hline
\end{tabular}

SD: Standard deviation; T: Total antigen; Ts: Sonicated antigen; M: Membrane antigen

a 1: sera from experimentally infected cattle; 2: sera from naturally infected cattle diagnosed during post-mortem inspection; 2a: sera from cattle naturally infected with more than one cysticercus; $2 b$ : sera from cattle naturally infected with one cysticercus; 3 : sera from cattle determined to be negative for cysticercosis during post-mortem inspection; 4: sera from cattle with other diseases.

The serum samples from cattle experimentally infected with Taenia saginata eggs showed positive results for all three antigenic preparations of Tcra, demonstrating a sensitivity of $100.0 \%$.

However, the sera obtained from cattle with natural cysticercosis showed some falsenegative reactions (Table 1), unlike the group of experimentally infected animals; these samples showed decreased sensitivity, ranging from 60.0 to $70.0 \%$ or 57.5 to $62.5 \%$, using SD of 2 and 3 , respectively.

This behavior was also observed in the naturally infected/positive animals evaluated in this study; these animals showed only one cysticercus during the post mortem investigations, and consequently displayed a lower ELISA sensitivity compared to the animals that displayed more than one cysticercus (Table 2).

Analysis of the cattle sera negative for cysticercosis during post-mortem inspection resulted in a satisfactory specificity, ranging from 72.5 to $82.5 \%$ and 80.0 to $95.0 \%$, with a SD of 2 and 3, respectively. However, all tested antigens gave a large number of false-positive reactions with the sera from cattle with other diseases, such as fasciolosis, hydatidosis, and tuberculosis. Therefore, the specificity of this analysis was low, and ranged from 22.5 to $47.5 \%$ and 37.5 to $52.5 \%$, with a SD of 2 and 3 , respectively, which demonstrated the crossreactivity between the infections.

Table 3 illustrates the frequency of negative reactions and the specificity for each disease, based on the antigen and the cut-off point. The sera obtained from cattle suffering from the three diseases (fasciolosis, hydatidosis, and tuberculosis) displayed high cross-reactivity with the different antigens. Fasciolosis showed the highest number of cross-reactions with antigen $\mathrm{T}$, hydatidosis with antigen Ts, and tuberculosis with antigen M. The specificity of fasciolosis was greater than $50 \%$ at a SD of 3, and upon using the antigens Ts and M; this was the only disease whose specificity exceeded $50 \%$.

The three Taenia crassiceps antigens provided similar results; the sensitivity was $\geq 60 \%$ for naturally infected animals. However, the ELISA OD values tended to vary between the antigens Ts, $\mathrm{T}$, and $\mathrm{M}$ (descending order OD). 
Table 3. Frequency of negative reactions to bovine cysticercosis, and specificity (\%) of ELISA in differentiating bovine samples with different diseases, according to the type of antigen and the cut-off point.

\begin{tabular}{|c|c|c|c|c|c|c|}
\hline \multirow{3}{*}{ Disease $^{\mathrm{a}}$} & \multicolumn{6}{|c|}{ Antigen/cut-off point (SD) } \\
\hline & \multicolumn{2}{|c|}{$\mathrm{T}$} & \multicolumn{2}{|c|}{ Ts } & \multicolumn{2}{|c|}{$\mathrm{M}$} \\
\hline & 2SD & $3 \mathrm{SD}$ & 2SD & $3 \mathrm{SD}$ & $2 \mathrm{SD}$ & $3 \mathrm{SD}$ \\
\hline Hydatidosis & $4(26.7)$ & $6(40.0)$ & $7(46.7)$ & $7(46.7)$ & $6(40.0)$ & $6(40.0)$ \\
\hline Fasciolosis & $2(13.3)$ & $4(26.7)$ & $7(46.7)$ & $9(60.0)$ & $7(46.7)$ & $8(53.3)$ \\
\hline Tuberculosis & $3(30.0)$ & $5(50.0)$ & $5(50.0)$ & $5(50.0)$ & $3(30.0)$ & $3(30.0)$ \\
\hline
\end{tabular}

SD: Standard deviation; T: Total antigen; Ts: Total sonicated antigen; M: Membrane antigen

aHydatidosis: 15 serum samples; Fascioliasis: 15 serum samples; Tuberculosis: 10 serum samples.

\section{Discussion and Conclusions}

The findings of several previously conducted studies are similar to the results of this study for experimentally infected cattle. Abuseir et al. (2007) also reported a sensitivity of $100.0 \%$, whereas Geerts et al. (1981) and Ogunremi and Benjamin (2010) obtained sensitivities of $96.88 \%$ and $92.9 \%$, respectively. Monteiro et al. (2006) also obtained satisfactory sensitivity rates (ranging from 75.0 to $90.0 \%$ ) for this category of control serum; however, these values were lower than those obtained in this study.

Pinto et al. (2006) tested the total antigen of Taenia crassiceps, and obtained a sensitivity of $90.0 \%$ with experimentally infected animals, using $2 \mathrm{SD}$ as the cut-off point, demonstrating the acceptable performance of ELISA in the detection of antibodies in experimentally infected animals.

Thomaz-Soccol et al. (2010) obtained a better antigenic sensitivity (83.6\%) for animals (bovines) naturally cysticercosis positive than that observed in this study. However, the sensitivity rates of both studies were higher than the sensitivity rates of post mortem inspections reported in previous studies (ABUSEIR et al., 2006; CALVO-ARTAVIA et al., 2012; EICHENBERGER et al., 2011; SCANDRETT et al., 2009).

In contrast to these results, some authors observed lower sensitivities of ELISA for the detection of antibodies produced by naturally infected animals; for example, Geerts et al. (1981), Monteiro et al. (2006), and Pinto et al. (2006) obtained ELISA sensitivities of $37.5 \%, 5.0$ to $31.6 \%$, and 3.3 to 20.0 $\%$, respectively.

The studies conducted in animals experimentally infected with different numbers of eggs confirmed the correlation between the levels of antibodies produced and the number of eggs ingested; in this case, the production of antibodies was observed to be gradual in animals with mild infections. In this sense, the major difficulty with serology for bovine cysticercosis is the low level of antibodies produced by animals with mild infections (SMITH et al., 1991).

The difference between the sensitivity in animals naturally and experimentally infected, which was also observed in other studies, could be attributed to the differences in the number of eggs ingested by the animals. Naturally infected animals usually display milder forms of the infections, as a result of the accidental ingestion of eggs dispersed in the environment; on the other hand, experimentally infected animals were inoculated with high doses of eggs $(120,000)$, and therefore demonstrated severe forms of the infection. Therefore, the intensity of the immune response could be proportional to the quantity of eggs ingested by the animal.

The few false-positive results observed for the cattle that tested negative during post-mortem inspection could be attributed to nonspecific reactions, as these animals were raised in the field, 
under uncontrolled conditions, and exposed to a variety of pathogens.

Ogunremi and Benjamin (2010) observed a similar specificity $(90.6 \%)$ for bovines that tested negative for cysticercosis. Thomaz-Soccol et al. (2010) also obtained a specificity of $92.8 \%$ with a 3 SD cut-off point, when analyzing sera from slaughtered cattle that tested negative for cysticercosis. Additionally, Geerts et al. (1981) also obtained a high specificity (94.0\%), revealing the detection of cysticercosis in two animals regarded as negative by post mortem inspection by ELISA; a more detailed examination of the carcass revealed that these animals were, in fact, infected with cysticerci.

The high occurrence of cross-reactions among the infections was in agreement with the results obtained by Kyvsgaard et al. (1991), who identified that the specificity of ELISA is the major obstacle towards its application in individual diagnosis. Therefore, one of the major reasons for the low specificity could be the major antigenic overlap that exists between cestoides and other parasites (SMITH et al., 1990).

Geerts et al. (1981) also observed crossreactions with bovine cysticercosis in an animal with fasciolosis; this was, however, not observed by Pinto et al. (2006) and Monteiro et al. (2006). A closer examination of the results obtained by Pinto et al. (2006) and Monteiro et al. (2006) revealed a small number of cross-reactions; however, these authors considered the number of samples tested to be limited, and cited the need for additional testing with a larger sample size. Geerts et al. (1981), who analyzed sera from cattle with other diseases, also concluded ELISA to be a very specific test.

A determining factor in the performance of ELISA is the cut-off point, which directly influences the sensitivity and specificity. As expected, the sensitivity of the test was observed to be higher when a SD of 2 was applied; when calculated with $3 \mathrm{SD}$, the sensitivity of the test was observed to decrease, despite the increase in specificity. Therefore, the cut-off point should be chosen according to the purpose of the test. As the major drawback of postmortem inspection is the low sensitivity, the $2 \mathrm{SD}$ cut-off point might be appropriate in order to use ELISA as the supplementary test, as it might detect a higher number of animals with mild infections that could go unnoticed during a routine inspection. In addition, the $2 \mathrm{SD}$ cut-off point is considered the norm in serodiagnostic tests (GREINER et al., 1995), especially in cases of prevalence screening during epidemiological studies of the disease.

The variation in ELISA results is a recurrent phenomenon, necessitating the continuous assessment of different laboratory protocols in order to increase the performance of the test. This performance increase was observed in this study, upon comparing the results of tests conducted by other study groups on naturally infected cattle using the same group of control sera.

The results, therefore, strengthen the importance of the appropriate selection of control sera groups (from cattle with different levels of infection) for ELISA for the diagnosis of bovine cysticercosis (which might have been a limitation of other studies, based on the low performance obtained).

Although the ELISA easily detects animals experimentally infected with high numbers of Taenia saginata eggs compared to animals with natural mild infections, the sensitivity was satisfactory for the diagnosis of bovine cysticercosis, enabling its applicability in field studies for screening of herds for the disease. The high performance of ELISA could be accredited to the use of heterologous Taenia crassiceps antigens, compared to the homologous $T$. saginata antigen, which resulted in a greater ease of maintenance, procurement, and implementation of the test.

Despite this, the specificity results showed that ELISA displays low performance when differentiating bovine cysticercosis from other diseases. Therefore, the combination of ELISA 
(using a cut-off point set to high sensitivity) and the highly specific pathological examination, would contribute to the accurate diagnosis and control of bovine cysticercosis, and the correct disposal of parasitized carcasses.

\section{Acknowledgements}

The authors would like to thank CNPq, CAPES, and FAPEMIG for the financial support provided.

\section{References}

ABUSEIR, S.; EPE, C.; SCHNIEDER, T.; KLEIN, G.; KÜHNE, M. Visual diagnosis of Taenia saginata cysticercosis during meat inspection: is it unequivocal? Parasitology Research, Heidelberg, v. 99, n. 4, p. 405409, 2006.

ABUSEIR, S.; KÜHNE, M.; SCHNIEDER, T.; KLEIN, G.; EPE, C. Evaluation of a serological method for the detection of Taenia saginata cysticercosis using serum and meat juice samples. Parasitology Research, Heidelberg, v. 101, n. 1, p. 131-137, 2007.

ALLEPUZ, A.; GABRIEL, S.; DORNY, P.; NAPP, S.; JANSEN, F.; VILAR, M. J.; VIVES, L.; PICART, L.; ORTUÑO, A.; GUTIÉRREZ, J.; CASAL, J. Comparison of bovine cysticercosis prevalence detected by antigen ELISA and visual inspection in the North East of Spain. Research in Veterinary Science, Amsterdam, v. 92, n. 3, p. 393-395, 2012.

BRASIL, MAPA - MINISTÉRIO DA AGRICULTURA PECUÁRIA E ABASTECIMENTO. Inspeção de carnes. Padronização de técnicas, instalações e equipamentos. Tomo I: Bovinos. Brasília: DIPOA/DICAR. 1971. 183 p.

CALVO-ARTAVIA, F. F.; NIELSEN, L. R.; ALBAN, L. Epidemiologic and economic evaluation of risk-based meat inspection for bovine cysticercosis in Danish cattle. Preventive Veterinary Medicine, Amsterdam, v. 108, n. 4, p. 253-261, 2012.

DORNY, P.; PRAET, N. Taenia saginata in Europe. Veterinary Parasitology, Amsterdam, v. 149, n. 1-2, p. 22-24, 2007.

EICHENBERGER, R. M.; STEPHAN, R.; DEPLAZES, P. Increased sensitivity for the diagnosis of Taenia saginata cysticercus infection by additional heart examination compared to the EU-approved routine meat inspection. Food Control, Amsterdam, v. 22, n. 6, p. 989992, 2011.
FUKUDA, R. T.; PRATA, L. F.; VERARDINO, H.; ALMEIDA, L. A. M. Evolução da cisticercose bovina em animais abatidos no Estado de São Paulo. Revista Higiene Alimentar, Mirandópolis, v. 17, n. 108, p. 2-31, 2003.

GEERTS, S.; KUMAR, V.; AERTS, N.; CEULEMANS, F. Comparative evaluation of immunoelectrophoresis, counterimmunoelectrophoresis and enzyme linked immunosorbent assay for the diagnosis of Taenia saginata cysticercosis. Veterinary Parasitology, Amsterdam, v. 8, n. 4, p. 299-307, 1981.

GREINER, M.; SOHR, D.; GOBEL, P. A modified ROC analysis for the selection of cut-off values and the definition of intermediate results of serodiagnostic tests. Journal of Immunological Methods, Amsterdam, v. 185, n. 1, p. 123-132, 1995.

KYVSGAARD, N. C.; ILSØE, B.; HENRIKSEN, S. A.; FELD, N. C.; NANSEN, P. Evaluation of an enzymelinked immunosorbent assay (ELISA) for detection of Taenia saginata cysticercosis in cattle. Acta Veterinaria Scandinavica, London, v. 32, n. 2, p. 233-241, 1991.

MINOZZO, J. C.; THOMAZ-SOCCOL, V.; OLORTEGUI, C. C.; SOARES, V. E.; COSTA, A. J. Teste imunoenzimático (enzyme-linked immunosorbent assay) para diagnóstico da cisticercose bovina e estudo da cinética de produção de anticorpos contra-Cysticercus bovis. Ciência Rural, Santa Maria, v. 34, n. 3, p. 857-864, 2004.

MIRANDA, Z. B. Inspeção de produtos de origem animal. Revista CFMV, Brasília, v. 26, p. 21-26, 2002.

MONTEIRO, L. L.; PINTO, P. S. A.; DIAS, F. S. Evaluation of the ELISA test for the antibody detection in cattle naturally and experimentally infected with Cysticercus bovis. Veterinary Parasitology, Amsterdam, v. 141, n. 3-4, p. 260-263, 2006.

OGUNREMI, O.; BENJAMIN, J. Development and field evaluation of a new serological test for Taenia saginata cysticercosis. Veterinary Parasitology, Amsterdam, v. 169, n. 1-2, p. 93-101, 2010.

OLIVEIRA, A. W.; OLIVEIRA, J. A. C.; BATISTA, T. G.; OLIVEIRA, E. R. A.; CAVALCANTI NETO, C. C.; ESPÍNDOLA FILHO, A. F. E. Estudo da prevalência da cisticercose bovina no estado de Alagoas. Acta Veterinaria Brasilica, Mossoró, v. 5, n. 1, p. 41-46, 2011.

PINTO, P. S. A.; MONTEIRO, L. M.; MINOZZO, J. C. A influência de diferentes grupos de soros-controle no diagnóstico da cisticercose bovina pelo teste ELISA. Revista Ceres, Viçosa, v. 53, n. 309, p. 574-579, 2006. 
SCANDRETT, B.; PARKER, S.; FORBES, L.; GAJADHAR, A.; DEKUMYOY, P.; WAIKAGUL, J.; HAINES, D. Distribution of Taenia saginata cysticerci in tissues of experimentally infected cattle. Veterinary Parasitology, Amsterdam, v. 164, n. 2-4, p. 223-231, 2009.

SCANDRETT, W. B.; HAINES, D. M.; PARKER, S. E.; ROBINSON, Y.; FORBES, L. B.; BRANDT, J.; GEERTS, S.; DORNY, P.; GAJADHAR, A. A. Validation of an immunohistochemical assay for bovine cysticercosis, with comparison to a standard histological method. Veterinary Parasitology, Amsterdam, v. 186, n. 3-4, p. 301-311, 2012.

SMITH, H. J.; SNOWDON, K. E.; FINLAY, R. C. Serological diagnosis of cysticercosis by an enzymelinked immunosorbent assay in experimentally infected cattle. Canadian Journal of Veterinary Research, Ottawa, v. 55 , n. 3 , p. $274-276,1991$.
SMITH, H. J.; SNOWDON, K. E.; GREGORY, D.; FINLEY, G. G. Assessment of an enzyme-linked Immunosorbent assay using a Taenia hydatigena fraction antigen in the diagnosis of cysticercosis in cattle. Canadian Journal of Veterinary Research, Ottawa, v. 54, n. 2, p. 299-300, 1990.

THOMAZ-SOCCOL, V.; SOUZA, V. K.; PESSOA, O. L.; MINOZZO, J. C.; PESSOA-SILVA, M. C.; PEIXOTO, R. P. M. G.; MOURA, J. F. Pesquisa de anticorpos contra Cysticercus bovis, por teste ELISA em bovinos de abatedouro. Archives of Veterinary Science, Curitiba, v. 15, n. 2, p. 77-85, 2010.

VAZ, A. J.; NUNES, C. M.; PIAZZA, R. M. F.; LIVRAMENTO, J. A.; SILVA, M. V.; NAKAMURA, P. M.; FERREIRA, W. Immunoblot with cerebrospinal fluid from patients with neurocysticercosis using antigen from cysticerci of Taenia solium and Taenia crassiceps. American Journal of Tropical Medicine and Hygiene, Deerfield, v. 57, n. 3, p. 354-357, 1997. 
